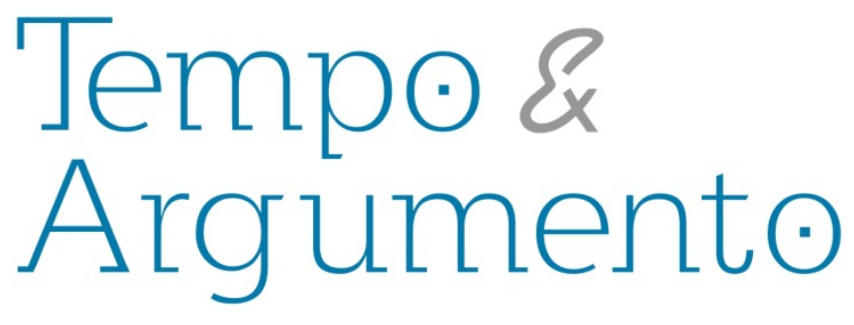

\title{
A UFPA e os Anos de Chumbo: A administração do reitor Silveira Neto em tempo de ditadura (1960 - 1969)
}

\begin{abstract}
Resumo
Este artigo tem por objetivo apresentar os primeiros anos do golpe civil-militar no Pará tendo como enfoque a Universidade Federal do Pará, entre os anos de 1960 a 1969, no mandato do reitor José da Silveira Neto e compreender, dentro do contexto específico da ditatura civil-militar, como foram os primeiros anos do regime, o debate sobre a necessidade da reforma universitária, a intervenção em algumas faculdades e os impactos do Al-5 e sua repressão a estudantes, professores e servidores públicos da UFPA após as ocupações de 68 na instituição.
\end{abstract}

Palavras-chave: Ditadura Militar. Memória. Al-5. Ensino Superior. Brsil - História (1960 - 1969).
Edilza Joana Oliveira Fontes Professora Dra associada III. Professora do Programa de História Social da Amazônia da Universidade Federal do Pará edilzafontes@yahoo.com.br

\section{Davison Hugo Rocha Alves}

Bacharel e Licenciado em História Universidade Federal do Pará davison.hugo@gmail.com

\section{Para citar este artigo:}

FONTES, Edilza Joana Oliveira; ALVES, Davison Hugo Rocha. A UFPA e os Anos de Chumbo: A administração do reitor Silveira Neto em tempo de ditadura (1960-1969). Revista Tempo e Argumento, Florianópolis, v. 5, n.10, jul./dez. 2013. p. 258 - 294.

\section{DOI: $10.5965 / 2175180305102013258$}

http://dx.doi.org/10.5965/2175180305102013258 


\title{
UFPA and the Years of Lead: The administration rector Silveira Neto time of dictatorship (1960 - 1969)
}

\begin{abstract}
This paper aims to present the first years of the civilmilitary coup in Pará having as focus the Federal University of Pará, between the years 1960 to 1969 , the mandate of the rector José da Silveira Neto and understand, within the specific context of civilmilitary dictatorship, as were the early years of the regime, the debate about the need for university reform, the intervention in some colleges and the impacts of $\mathrm{Al}-5$ and its repression of students, teachers and civil servants UFPA after occupations 68 in the institution.
\end{abstract}

Keywords: Military Dictatorship. Memory. Al-5. Higher Education. Brazil History (1960 - 1969).

No Brasil a década de 60 iniciou-se com a efervescência do golpe civil-militar, em 1964․ A historiografia que debate o golpe de 1964 no Brasil, já possui um consenso de que o golpe só foi possível por uma conjunção de forças que iria além das forças armadas,

\footnotetext{
1 Usamos neste artigo a definição de golpe civil- militar por concordarmos com o debate atual da historiografia que indica a participação de setores civis para implantação dos governos militares no Brasil em 1964. Ver FICO Carlos. Além do golpe: a tomada do poder em 31 de março de 1964 e a ditadura militar. Rio de Janeiro: Record, 2004; TOLEDO, Caio (Org.) 1964: visões críticas do golpe. Democracia e reformas no populismo. Campinas: Unicamp, 1997; REIS, Daniel. A ditadura militar, esquerdas e sociedade. Editora Jorge Zahar, 2010.
} 
Silveira Neto ${ }^{2}$ e compreender, dentro do contexto específico, como foram os primeiros anos do regime, o debate sobre a necessidade da reforma universitária ${ }^{3}$, a intervenção em algumas faculdades os impactos do $\mathrm{Al}-5$ e sua repressão a estudantes ${ }^{4}$, professores e servidores públicos da UFPA após as ocupações de 68 na instituição 5 .

Entre as fontes que utilizaremos estão os jornais da grande imprensa do Pará, que foram amplamente favoráveis ao golpe, como, Folha do Norte ${ }^{6}$, A Província do Pará $^{7}$ e 0 Liberal $^{8}$, que defenderam o golpe civil-militar, ora ostensivamente, ora disfarçadamente.

\footnotetext{
2 José da Silveira Neto graduou-se em medicina em 1938, passou a ser funcionário da Faculdade de Medicina em 1944 e em 1946 fez concurso para a cátedra de Higiene e Medicina Preventiva. Com a lei nº 3.191, a Faculdade de Medicina foi federalizada.
}

${ }^{3}$ A reforma universitária de 1968 apesar de ter uma profícua bibliografia, no entanto, carece de pesquisa no Pará. Ver SAVIANI, Demerval. Sociedade de Classes e Reformas Universitárias. Autores Associados. 2007; DIAS, Janaina. A Reforma Universitária de 1968 e o processo de reestruturação da UFRGS (1964-1972): uma análise da política educacional para o ensino superior durante a ditadura civil-militar brasileira. Editora Universidade Vale dos Sinos. São Leopoldo, RS, 2009.

${ }^{4}$ Há uma lacuna historiográfica sobre a repressão dos estudantes durante os primeiros anos da ditadura civil-militar no Pará.

${ }^{5}$ Não há uma historiografia sobre o tema aprofundado no Pará.

${ }^{6}$ O jornal A FOLHA DO NORTE (1896/1974) foi fundada com objetivo de defender os ideais do partido republicano, em 1964 desempenhou o papel, inicialmente, de defesa aos movimentos da revolução, publicando noticias que davam certo apoio ao golpe militar, com manchetes do tipo "As forças armadas e o povo venceram a luta...", "Bravos mineiros, o Brasil vos saúda!" e "A nação unida às forças armadas", eram comuns essas notícias. Além de darem apoio ao golpe, as notícias procuravam sempre demostrar que o povo apoiava os ideais da chamada "revolução de 1964". Foi criada neste jornal uma coluna, de fim de semana, chamada de "O informante invisível" que, divulgava listas de suspeitos recomendando suas prisões.

7 O jornal O Liberal (1946- ....) ao ser adquirido por Rômulo Maiorana em 1966, passou a integrar Organizações Rômulo Maiorana (ORM), que atualmente é um dos maiores grupos de comunicação do Brasil, ele é considerado um dos veículos mais lidos do Estado e o único jornal com prêmios internacionais no Norte/Nordeste.

${ }^{8}$ O jornal A PROVÍNCIA DO PARÁ (1876-2001) foi um periódico que circulou em Belém do Pará, no estado do Pará, no Brasil. Fundado em 25 de março de 1876 por Joaquim José de Assis1 (criador, entre outras publicações, do periódico maçom "O Pelicano" e do periódico republicano "O Futuro", ambos em 1872), circulou como jornal diário por 125 anos. Durante o ciclo da borracha, pertenceu ao então intendente de Belém Antônio Lemos. Em 1947 integrou o grupo dos Diários Associados, tendo sido vendido, em 1997, para o grupo paraense dono da Editora Cejup. Foi novamente vendido em 2001, quando deixou de circular. $\mathrm{Na}$ época em que sua publicação foi descontinuada, era o jornal de menor circulação entre os três diários de Belém. 
Os jornais de Belém aceitaram a tese que havia um inimigo subversivo da democracia, das tradições, da ordem e que era necessário combatê-lo. Aceitaram também a tese de que os militares eram os heróis combatentes. Muitos artigos foram escritos de forma a exaltar as forças armadas, em alguns momentos chegaram até aparentar que antes do golpe de 1964 no Brasil não vigorava uma democracia. Os jornais de Belém defenderam para combater o inimigo subversivo da democracia, das tradições, da ordem heróis combatentes, que eram os militares. Muitos artigos foram escritos de forma a exaltar as forças armadas.

Usaremos também livros de memórias como: 1964: Relatos Subversivos - os estudantes e o golpe civil-militar no Pará (2004), onde constam os relatos de oito exalunos que em março de 1964 foram presos, responderam a Inquéritos Policiais Militares (IPM) e tinham um importante destaque no movimento estudantil da época. Outro livro UFPA 50 anos - Relatos de uma trajetória (2007), lançado em comemoração ao aniversário da Universidade Federal do Pará é um interessante livro de memórias sobre as experiências coletivas de 22 professores aposentados ou em exercício na Universidade que viveram os anos 60 especificadamente, Outro livro é a UFPA 50 anos - História e Memória (2007), que nos conta um pouco da história da instituição desde sua fundação em 1957 até 2007. Para este artigo nos interessa somente compreender a Universidade Federal do Pará, em tempos de ditadura militar no mandato do reitor Silveira Neto.

Outro destaque será o uso de memórias de professores que durante os anos 60 foram alunos da universidade, disponíveis no repositório multimídia da Universidade Federal do Pará9. Este repositório tem arquivado 87 entrevistas com professores, servidores e ex-alunos da UFPA. A plataforma é bilíngue permitindo o acesso aos

9 No link http://www.multimidia.ufpa.br/jspui/ estão as entrevistas concedidas ao projeto Universidade Multicampi: 25 anos de ensino superior regionalizado no Pará. O projeto pretende pesquisar os 25 anos do processo de interiorização da UFPA de 1986 a 2011, usando como fontes a documentação institucional (atas dos conselhos superiores, documentação do departamento de seleção - antigo DAVES, documentação do departamento de pessoal, atas dos conselhos de centro, documentação da reitoria e pró-reitoras), além de trabalhar com a memória dos vários segmentos envolvidos no processo de interiorização da UFPA. Depoimento de professores, servidores, alunos, egressos e autoridades locais, são partes da memória que pretendemos sistematizar. Assim como a documentação iconográfica e os documentos institucionais produzidos pela UFPA, que indicam as várias fases pelo que passa o processo de interiorização da universidade. 

documentação expedida e recebida pelo gabinete do reitor Silveira Neto. Nossa intenção é analisar o espaço micro, no caso a UFPA, e perceber as relações construídas no dia a dia da instituição e refletir sobre as políticas governamentais, pensadas pelos governos militares e como elas estabeleceram conflitos, relações de negociação e promoveram constrangimentos, violação de direitos humanos e propiciaram a construção de memórias (POLLACK, 1992, 205) individuais, que se consolidaram como coletivas (HALBWACHS, 1990, p. 56).

\section{As memórias da gestão de Silveira Neto (1960 - 1969)}

Em 19 de dezembro de 1960, tomou posse José Rodrigues da Silveira Neto, que ocupou a reitoria durante oito anos e meio. Em 1957, ano de criação da Universidade do Pará, José da Silveira Neto, já era diretor da Faculdade de Medicina - uma das três federalizadas - e candidato a ser o primeiro reitor da Universidade do Pará. A indicação não aconteceu pelo fato de ele não ter o apoio do governador do Estado, Major Magalhães Barata, que apoiou Mario Braga Henriques da Faculdade de Direito (BECKMANN, 2006, p.13).

O Jornal “A província do Pará”, no dia 05 de março de 1964, divulga uma nota da Universidade Federal do Pará, assinada pelo reitor Silveira Neto e redigida pelo Departamento de Educação e Ensino, afirmando que "levando em consideração a atual situação nacional, de ordem do Magnífico Reitor, fica suspensa as atividades escolares em todas as unidades e Cursos Universitários, até ulterior deliberação", segundo o diretor em exercício Octavio Cascaes. A professora Nilza Fialho ${ }^{10}$ comenta em depoimento que a

\footnotetext{
10 UNIVERSIDADE FEDERAL DO PARÁ. Reitoria. Universidade Multicampi - 25 anos de ensino superior regionalizado no Pará: entrevista Nilza Fialho de Andrade. Belém: UFPA, 2012. 1 vídeo (1h 21min e 10seg). Disponível em: <http://www.multimídia.ufpa.br/jspui/handle/321654/1069>. Acesso em: 07/08/2013.
} 
Universidade Federal do Pará vivia um clima de tensão em 1964 e a atuação do movimento estudantil era forte

Nesse tempo que antecedeu o golpe de 64, o centro acadêmico tinha uma atuação grande na faculdade de Filosofia mesmo de lá, então havia movimentos, passeatas contra a criação do grande largo amazônico, contra o projeto americano, contra a esterilização das mulheres na Amazônia, se panfletava, se saia para rua, se aproveitava o trote pra fazer críticas, reivindicar, para fazer denúncias, então isso na época era permitido, então houve a ocupação da universidade, por melhorias de condições, por melhorias de salários, de fato mesmo os alunos ocuparam, ficaram lá mesmo na Faculdade não deixaram ninguém entrar, então havia, não havia uma consistência maior política, não havia um apoio político maior, então eu sempre digo que é uma revolução de flores sem pedradas, a gente era muito sonhador, a gente pensava que iria resolver tudo sonhando, com a ideologia que o mundo vai ser melhor, fazer uma ideologia com uma revolução de flores.

No livro "UFPA 50 anos: relatos de uma trajetória", as memórias do professor Roberto Cortez ${ }^{11}$ que à época era presidente do diretório da Faculdade de Filosofia, Ciências e Letras, declara a perseguição sofrida pelo reitor Silveira Neto, depois de uma passeata organizada pelos estudantes, segundo Cortez em 1964, no início de março houve uma greve geral que ocorreu com a adesão de alguns cursos como o curso de Química e de Serviço Social. A greve foi rápida e muito importante para consolidar uma oposição ao reitor Silveira Neto, foi uma greve contrária às ações do reitor em relação à extinção do curso de Bacharelado em História e Sociologia. Questionava-se a qualidade dos cursos ofertados pela Universidade e as vagas que não eram preenchidas para os cursos da Faculdade de Filosofia. O professor José Paes Loureiro ${ }^{12}$ lembra os anos difíceis, que foram o mandato do reitor Silveira Neto. Segundo ele a universidade estará subordinada ao regime militar, onde o campus que se instalou no Guamá não pode se tornar, "a curto ou médio ou quase longo prazo, o desejado 'lócus' de liberdade de ideias,

\footnotetext{
${ }^{11}$ Sociólogo e antropólogo, pesquisador aposentado.

${ }^{12}$ Poeta. Professor de Estética, Arte e Cultura Amazônica UFPA, foi considerado subversivo e impedido pelo SNI de assumir o cargo de professor durante a administração de Aloysio Chaves e Clóvis Malcher.
} 
o Dr. Alcyr Meira ${ }^{13}$, que havia sido nomeado engenheiro da Universidade, ainda no mandato do Dr. Mario Braga Henriques, relembra os três primeiros anos da Universidade do Pará como tempos de dificuldades administrativas e infraestruturas. Tempo de poucas mudanças, em geral reformas de prédios das antigas faculdades que eram precários. É o próprio Alcyr Meira que compara as administrações da Universidade e exalta o Dr. Silveira Neto como um grande construtor, como um indômito timoneiro, aquele que deu todo seu esforço para consolidação do Campus e para ampliação dos cursos da UFPA, destacando que ele "transformou a universidade em uma entidade dinâmica, referendando o seu papel de geradora de recursos humanos de alta qualificação" (MEIRA, 2006, p.12). O reitor Silveira Neto é lembrado pelo professor Alcyr Meira, como quem executou uma ampla reestruturação acadêmica e administrativa, sendo responsável por uma reforma educacional na universidade que definiu normas e diretrizes para pesquisa e projeto de extensão. Durante sua administração a instituição teria pessoas altamente qualificadas e competentes.

Ocorre que esta memória é contraposta a outra que coloca as relações políticas do reitor com os governos militares, de seus embates com os estudantes e professores nos anos sessenta, como elementos para defini-lo como administrador autoritário, de pouco diálogo, centralizador e implacável com seus adversários. Não fizemos a escolha por uma das memórias. Provavelmente as duas são resultados de experiências de pessoas posicionadas distintamente nas esferas sociais e que se relacionaram com o reitor de formas diferenciadas. Ele sem dúvida foi um bom administrador em época de ditadura. Procuraremos ressaltar as obras do reitor Silveira Neto e as várias memórias consolidadas sobre este homem que foi um reitor da confiança dos governos militares e devido às relações estabelecidas foi também um fiel escudeiro do regime na UFPA.

\footnotetext{
${ }^{13}$ Professor Aposentado e ex-vice-reitor da UFPA na administração de Silveira Neto.
} 
A ideia de construção de um campus, local onde ficassem abrigadas todas as instalações, edificações e equipamentos já era secular na Europa e começava a dar seus primeiros passos nos EUA. No Brasil, estava ocorrendo a construção de três campi universitários, no Rio de Janeiro, São Paulo e Recife. O reitor José da Silveira Neto começa uma série de reformas administrativas e estruturais. Os dois primeiros anos de seu mandato foram dedicados às áreas administrativa e acadêmica, com reformulação do Estatuto em 1963, com o objetivo de agilizar a organização administrativa e as políticas educacionais, além de garantir diretrizes de pesquisa e extensão. A lei nº 4.283 de 18 de novembro de 1963 reestruturava a Universidade, criando novos cursos e ampliando o número de vagas. Incluiu o Instituto de Higiene e Medicina Preventiva na estrutura da Universidade, ampliou o período de mandato de reitor e dos diretores de três para cinco anos, criou os Conselhos Departamentais dos órgãos e aumentou a representação discente nas instâncias universitárias, integrou a Escola de Serviço Social e a Escola de Química Industrial à Universidade, regularizando a situação e ampliando o corpo docente.

É na gestão do reitor Silveira Neto que começam a ser dados os primeiros passos rumo à construção do campus. O primeiro foi a compra do Palacete Augusto Montenegro, na Av. Governador José Malcher - hoje museu da Universidade - onde foi instalada a reitoria da Universidade em substituição ao sobrado de $n^{\circ}$. 61 da Avenida Nazaré. Também foi comprado outro palacete para abrigar o Departamento Administrativo e Financeiro (MEIRA, 2006, p.125).

Houve neste período um aumento no número de vagas para os cursos, ampliação e reformas das unidades, reforma e ampliação do prédio da Faculdade de Direito, onde foram anexados três pavimentos destinados ao serviço de prática jurídica. Tivemos a reconstrução do prédio de Farmácia, a ampliação do prédio da Faculdade de Odontologia, a criação da Escola Primária. A primeira reforma estatuária da Universidade aconteceu em 1963, dois meses após esta reforma a Universidade foi reestruturada pela Lei n. 4.283, de 18 de novembro de 1963.

Em 1964 começam as discussões sobre a construção do campus universitário. O primeiro passo dado pela reitoria foi a elaboração de um Termo de Referência em edital, definindo as condições mínimas para o terreno onde seria implantado o campus e o 

doado pelo IPEAN, era necessário que mais terras no entorno fossem desapropriadas e, apesar dos entraves, sete terrenos foram desapropriados e incorporados ao patrimônio da Universidade.

As obras da construção do campus iniciaram com o aterramento da área por meio de caçambas basculantes feito pela empresa Celestino Rocha Engenharia, que buscava material arenoso em suas jazidas localizadas em Ananindeua. Este processo com o passar do tempo se demonstrou oneroso, lento e ineficaz. Visando superar este problema, o Dr. Alcyr Meira pensou na possibilidade de realizar o aterramento utilizando areia do próprio rio Guamá, processo conhecido como aterramento hidráulico. Foram feitos estudos batimétricos que viabilizaram a ideia, entretanto, seria necessária uma draga de sucção dotada de desagregador (MEIRA, 2006, p.131). Foi feito contato com o DNOS, que possuía tal draga sendo utilizada no porto de Curitiba. Imediatamente Alcyr Meira embarca para Brasília, com o consentimento do reitor, para falar com o Ministro dos Transportes, que autoriza a ida da draga de Mato Grosso para Belém. Em duas semanas o trabalho de aterramento já estava quase concluído e o terreno pronto para ser ocupado.

Uma questão suscitada no mesmo período da construção do campus diz respeito aos alunos excedentes. Para Eidorfe Moreira ${ }^{15}$, esta questão só veio acentuar-se na Universidade do Pará em fins de seu primeiro decênio e foi considerado um dos principais problemas para a instituição naquele momento. Após várias manifestações estudantis, no Brasil inteiro, o MEC autoriza a matrícula dos excedentes, repassando a responsabilidade para as Universidades, que não tinham estruturas para atender à demanda. Deste modo, a reitoria toma medidas de emergência como a construção de anexos aos prédios das faculdades e contratação de professores temporários.

\footnotetext{
${ }^{14}$ Ata da $12^{\text {a }}$ sessão do Conselho Universitário realizada em 9 de junho de 1964.

${ }^{15}$ Professor e pesquisador da Universidade Federal do Pará onde exerceu várias funções, afastando-se em 1982, foi um crítico de arte e literário que utilizava a geografia como elo, para entender a região amazônica, fazendo parte da administração de Silveira Neto.
} 
Em reunião realizada no dia 8 de Agosto de 1968 no Conselho Universitário, de acordo com o processo $\mathrm{n}^{\circ}$ 07874/68 que tinha como interessado a Reitoria da Universidade do Pará, é outorgado o título de "Doutor Honoris Causa" ao então presidente da República, à época do Marechal Arthur da Costa e Silva. O título foi entregue na inauguração do campus Universitário do Guamá, como reconhecimento ao "homem que teve relevância no empreendimento" e foi aprovado por unanimidade. No dia 13 de agosto de 1968 é inaugurado o Conjunto Universitário com a presença do presidente Costa e Silva e todo o seu Ministério. Coube ao Dr. Alcyr Meira a responsabilidade de fazer uma exposição sobre o conjunto universitário inaugurado após quatro anos do início do projeto.

\section{Movimentos Sociais na Universidade e os Primeiros Anos dos Governos} Militares.

Nos anos 50, a União Acadêmica Paraense (UAP) tinha um papel muito significativo em relação ao projeto da Universidade. Em torno da UAP se travaram lutas estudantis, sobretudo nos anos que antecederam 1964. Havia uma participação efetiva dos universitários na vida do país. Eram eles que participavam das grandes questões nacionais, como a reforma agrária e a questão do petróleo. Vivia-se sob o impacto e a influência da revolução cubana. Os estudantes viam-se como revolucionários, como vanguardas da mudança. Discussões como a questão angolana, a questão de Cuba, os problemas das madeiras na Amazônia, a construção da Belém - Brasília, que levava recursos da Universidade, eram debatidas e a linha política da UAP estava vinculada com questões nacionais, como comenta Pedro Galvão, "tinha uma linha nacionalista que repercutiu muito em todos nós. Hoje são líderes em suas atividades. A UAP teve uma postura nacionalista, mas a posição regionalista também foi de fundamental importância”. (FONTES, 2007, p.55)

Formada em uma conjuntura singular dos fins dos anos 50 e início dos anos 60, a UAP é rememorada por vários militantes estudantis como uma boa escola, que formou muita gente. Estes jovens pertenciam a uma parte radical da classe média e estabeleceram, em seu fazer político, bandeiras de lutas do movimento estudantil dos 
anos 60, intimamente relacionadas com o setor da classe à qual pertenciam. Este seguimento universitário estava em expansão, chegando a 42 mil em 1950, 93 mil em 1960 e 142 em 1964, em todo Brasil (FILHO, 1997, p. 78).

Em 1960, apenas 1\% da população chegava à Universidade (HOBSBAWM, 2011, p. 65). A UNE era respeitada e era uma juventude interessada em mudar o Mundo, mas não só isso. Animava-nos o desejo de ver implantada a solidariedade ao invés da competição. Havia também um processo de produção da cultura na configuração do movimento estudantil, que já envolvia alguma massificação cultural. A partir dos programas de rádio transmitidos pela PRC5 (Rádio Clube do Pará), produzidos pela diretoria da UAP, podemos perceber que o movimento estudantil da época foi constituído, também, como o movimento cultural. Os universitários pertenciam a um extrato social de classe média, e essa geração estudantil estabeleceu uma prática cultural específica.

Nos anos JK, a UNE travara campanhas nacionalistas com vínculo popular, o que possibilitou um processo de politização dos universitários. Esta politização foi efetivada, em grande parte, pela Juventude Universitária Católica (JUC), pela Juventude Estudantil Católica (JEC) e pelo Partido Comunista Brasileiro. A JUC juntava existencialismo cristão com nacional desenvolvimentista, tinha uma aspiração humanista e um personalismo católico, o professor Heraldo Maués ${ }^{16}$ em entrevista a Universidade nos argumenta que.

Esse período coincidiu com o período em que a JUC passa a assumir uma política de esquerda dentro da Igreja Católica e convoca a se reorganizar a JUC no Pará. O que permitiu que os militantes da JUC pudessem atuar politicamente nos diretórios. No diretório de filosofia, era membro da JUC, que tinha ramificações em outras faculdades como direito, agronomia, medicina, agora todo esse movimento da JUC acabou resultando na formação da Ação Popular que é um fenômeno importante nesse movimento da esquerda católica brasileira e a AP se constituiu de uma forma bastante ampla e tendo como base os militantes da JUC, mas evidentemente tinha participação de outras pessoas que não tinham passado pela JUC. Havia uma divisão, entre esquerda e direita, uma esquerda comunista e uma esquerda católica. Esquerda católica, que hoje reputo bastante ingênua, populista. Essa questão passou a se tornar

\footnotetext{
16 Universidade Multicampi - 25 anos de ensino superior regionalizado no Pará: entrevista Raymundo Heraldo Maués. Belém: UFPA, 2012. 1 vídeo (02h 05min e 07seg). Disponível em: <http://www.multimidia.ufpa.br/jspui/handle/321654/1057>. Acesso em: 07/08/2013.
} 
mais clara porque se colocava uma dicotomia entre populismo e vanguardismo, enquanto que o partido comunista através do CPC era muito influenciado pelo partido comunista, se colocava numa postura vanguardista, a esquerda católica se colocava mais numa postura populista e isso acabou resultando na passagem de muitos desses elementos que atuavam inicialmente na JUC e depois na AP para Movimento de Educação de Base que é o MEB, pertencia a CNBB e essa luta acabou se transferindo para o campo. Porque novamente no campo iam se encontrar antigos militantes da JUC, militantes da AP e que se confrontavam com militantes comunistas que também estavam interessados na sindicalização rural embora fossem duas esquerdas, eram esquerdas que tinham suas diferenças onde algumas ocasiões se uniam em outras se separava.

O professor Raymundo Maués foi um militante da AP no Pará e chegou a ser um

de seus coordenadores no estado nos anos sessenta.

depois que eu entrei para a universidade eu passei a ser ligado a JUC, num determinado momento eu cheguei a ser dirigente da JUC em Belém. Era toda uma organização, era o grupo mais avançado da Ação Católica, era a época do Betinho o principal líder da JUC nacional. Neste momento também foi criada a AP (Ação Popular) que foi a última tentativa de criação de um partido católico no Brasil. Era a proposta de um partido católico de esquerda, participei dessa coisa toda, entre as pessoas que participaram estava a Elisa que depois casou com Samuel Sá, Almerinda, Roberto Valente, enfim, várias pessoas que participaram dessa atividade ligado a JUC participando da política estudantil numa posição de esquerda digamos com divergências, também em relação ao partido comunista, mas com alianças também era uma situação complexa, se aliava mas também havia divergências internas. Eu entrei em 1959, deve ter sido em1960 ou 1961, eu saí em 1962, por que eu cursei até 1962. Nesse momento estava se configurando toda uma luta política estudantil em plano nacional pela reforma universitária, era uma das reformas de base, do ponto de vista dos professores a figura mais importante era o Darcy Ribeiro. A UNE organizou um grande congresso na Bahia, congresso sobre a reforma universitária, as nossas grandes reivindicações eram, por exemplo, a abolição da cátedra, a realização de concursos para professores, por que não havia concursos, os professores entraram por indicação dos catedráticos. O meu currículo era melhor, eu fiquei nos dois primeiros lugares nos dois concursos, só que eu podia esperar isso também meu nome foi vetado pelo SNI. Era o SNI que tinha agentes aqui, que vigiava todas as universidades do Brasil, e que em casos desse tipo eles vetavam as pessoas que não queriam, o concurso foi em 71, há um detalhe que eu deveria dizer também, antes disso em 1969, já na vigência do Al-5 houve uma denúncia contra os dirigentes da $\mathrm{AP}$, aqui em Belém, os dirigentes da AP era Eu, Roberto Valente, Almerinda, Elisa Sá, Félix Coqueiro. A denúncia maior era contra mim, mas a denúncia era um pouco vaga, o que nós sabemos depois do 
processo, houve uma confissão, a gente não sabe como foi obtida, sobre tortura que indicava pessoas daqui, inclusive o professor Maués dos Correios. A denúncia era assim um tanto vaga, e eles chegaram até a importunar um colega nosso do correio, mas que não era eu e depois chegaram à conclusão de que não era este senhor. Quando chegaram à conclusão que era eu eles montaram todo um esquema para me prender. Prenderam a mim, o Valente, nós ficamos incomunicáveis, com o exterior, na verdade nós ficamos no mesmo quarto, um quarto de oficiais, onde ficamos presos na Aeronáutica, fomos torturados, mas enfim, nós já tínhamos nos afastado da AP, (..) [Quanto tempo o senhor ficou preso?] um mês, [Onde o senhor ficou?] no quartel da Aeronáutica, [E que tipo de tortura eles fizeram com o senhor?] Aqueles tapas no ouvido, faziam uma encenação, havia dois majores que tomavam conta de nós, o major Ulisses e o outro eu não consigo lembrar o nome, que era o negro (...) pois é, um era o bom o outro era o mau, o Ulisses era o bonzinho, o negro era o mauzinho, aí em alguns momentos altas horas da noite, ele ia e nos pegava, individualmente, nos levava para uma sala, onde havia várias pessoas fortes, que nos davam essas tapas e queriam que a gente confessasse as coisas, aí num determinado momento o major Ulisses chegava lá, vamos acabar com isso, vocês estão cometendo um abuso, quer dizer ele era o bonzinho, mas a ameaça estava sempre presente, só que nós não sabíamos mais de nada, nós havíamos nos desvinculado totalmente, eles conseguiram, também, saber dos outros nomes por uma série de razões, (...) aí em um determinado momento como eles não tinham mais como nos manter presos, nós fomos soltos, Valente e Eu (...).

Como podemos observar, o professor Heraldo Maués tem uma memória muito interessante sobre as atuações dos governos militares na Amazônia em relação principalmente a professores, estudantes e servidores que sofreram perseguição política, realizada por agentes públicos, nomeada na segunda metade dos anos 60 e que no nosso entendimento são memórias importantes para análise da História da Amazônia, mais precisamente sobre a década de 60/70 e a relação de educadores e servidores da UFPA com os governos militares. O professor Heraldo Maués menciona o processo aberto contra ele no SNI junto ao conselho permanente de Justiça da Aeronáutica da $8^{\text {a }} \mathrm{CJN}$ com base no artigo 9 da lei $n^{\circ}$ 1802/53. A denúncia foi feita em 29 de dezembro de 1969 e foi recebida em 15 de janeiro de 1970 por que,

Em épocas anteriores a revolução democrática de 31 de março, os estudantes universitários participaram de vários movimentos esquerdistas que se desenrolaram no âmbito estudantil no Pará destacadamente naquele que foi denominado inicialmente como o nome 
de "GRUPÃO" e que mais tarde ficou conhecida como Ação Popular (AP) (GALVÃO, 2004, p.30).

Em 1961, na ocasião do $24^{\circ}$ congresso da UNE, Aldo Arantes é eleito e a JUC passa a ser a liderança do Movimento Estudantil brasileiro. Podemos dizer que havia uma esquerda cristã e que em 1961 e 1962 esta esquerda dirigia a UNE e assumia como sua bandeira prioritária a Reforma Universitária. A UAP reafirma em suas notas e suas ações políticas a sua vinculação com a UNE e a esse projeto político. No Pará houve uma UNE volante na gestão de Aldo Arantes (Julho de 61 a Julho de 62).

Em janeiro de 1961 o recém-empossado reitor José da Silveira Neto decide no uso de suas atribuições negar a aprovação do regimento do $D C E^{17}$. Desde a sua fundação, os estudantes não tinham constituído sua representação nos órgãos dirigentes da Universidade. Este fato acirra os ânimos para a greve de 1/3 de 1962. Em 1962 a União Nacional dos Estudantes realiza a greve em favor da participação estudantil de 1/3 do conjunto dos membros dos Colegiados Superiores. No Pará, a UAP adere à greve e paralisa toda a Universidade Federal do Pará. Em depoimento, o presidente da UAP, estudante de Direito Pedro Galvão ${ }^{18}$, declara que,

A greve de um terço que paralisou todos os alunos do Pará, ninguém furou a greve. Os estudantes paravam os ônibus e brigavam com a polícia. Com relação à reforma universitária, o grande modelo na época estava voltado para a Universidade de Brasília onde estava sendo implementada isso e em termo dessa forma, como ela estava sendo encaminhada, poderia ser nova esperança para a Universidade brasileira. Aqui na Universidade do Pará havia apenas os prédios da Faculdade de Direito, de Medicina, Filosofia onde as instalações eram bastante precárias. Então, os professores autorizaram, embora tivéssemos professores bastante competentes, tínhamos professores extremamente incompetentes. Havia um reitor na Universidade da Bahia que estava há 15 anos na reitoria da Universidade, há enfim, essas questões todas além da necessidade da democratização, da participação estudantil nos órgãos colegiados da Universidade, eram todas as bandeiras de lutas do movimento universitário. Pretendia-se melhorar a Universidade em vários níveis não só nas questões materiais, não só democratizá-la, mas também melhorar o nível de ensino que considerávamos bastante baixo. O reitor

\footnotetext{
${ }^{17}$ In: Reunião Extraordinária do CONSUN de 18 de janeiro de 1961.

${ }^{18}$ GALVÃO, P. Vencido Vencedores. In: Galvão, Pedro. 1964 - Relatos Subversivos: Os estudantes e o golpe no Pará. Belém: Edição dos Autores, 2004,pp.30
} 
na época, José da Silveira Neto, era uma pessoa totalmente contrária a qualquer movimento reivindicatório dos estudantes, e naquela ocasião resolvemos realmente enfrentá-lo. Realizamos uma passeata estudantil que culminou com uma manifestação em frente à reitoria, onde vários estudantes discursaram falando da Reforma Universitária. Na ocasião, a reitoria manteve-se fechada, sem qualquer movimento.

Na referida passeata, os estudantes, além de reivindicar sua participação nos Conselhos Superiores, manifestavam-se também em relação ao problema do vestibular e do regime de dependência em matérias. Quanto ao vestibular, os estudantes lutavam contra o processo seletivo elitista, que se refletia em todas as universidades brasileiras. Essa insatisfação já era evidente desde $01^{\circ}$ Seminário Nacional sobre a Reforma Universitária promovido pela UNE em 1961, quando foi sugerido o prévio exame vocacional aos candidatos ao vestibular. Já no $2^{\circ}$ Seminário, em 1962, a proposta passa a ser o da supressão do vestibular em todas as Universidades brasileiras.

No fim dos anos cinquenta, havia uma luta muito grande para encampar a Faculdade de Serviço Social e a Escola de Química na Universidade. O Diário Oficial do Estado, de 19 de janeiro de 1961, publicou a autorização para que o governo do Estado providenciasse a encampação e iniciasse entendimentos com as autoridades competentes, para que a Escola de Química Industrial do Pará fosse integrada à Universidade do Pará. A Lei Federal N 4.283 de 18 de novembro de 1963 federaliza a Escola de Química e esta passou a fazer parte da Universidade do Pará. Em 1962 o Instituto Ofir Loiola em Ofício número 45/61 ressalta que é a entidade mantenedora da Escola de Serviço Social do Pará e que tomou conhecimento que a Universidade do Pará em reunião deliberou sugerir à mesa diretora dessa instituição a agregação da Escola à Universidade do Pará. O instituto esclarece que se reuniu e decidiu acatar a sugestão da Universidade, porém propõe que a Escola permaneça vinculada ao Instituto, ao mesmo tempo em que agregada à Universidade do Pará, mas a incorporação da Escola de Serviço Social só obtivera bons resultados anos depois.

Lauro Morhy foi eleito em julho de 63 para a tesouraria da UNE no Congresso de Santo André. Era presidente do diretório de química e havia dirigido a luta de incorporação da Escola de Química à UFPA. Era militante da AP e sua indicação para o 
cargo demonstra a articulação dos universitários do Pará com o movimento nacional. No Pará, tivemos teatro universitário, jornal tabloide UNE volante em 1962, apresentação da peça de teatro "Cinco vezes favela", o que representa uma articulação cultural bastante vinculada à luta estudantil.

Lembro-me do episódio ocorrido no dia 30 de março de 1964. Nós estávamos ali, eu na presidência da UAP, nós estávamos na sessão de abertura do $1^{\circ}$ Seminário Latino Americano sobre Reforma Universitária. A sessão de abertura foi realizada ali no auditório da Faculdade de Odontologia e fica na praça Batista Campos, onde o prédio acaba de ser vendido ao Bradesco. Naquela época nós fizemos a abertura desse primeiro seminário. Inclusive tinha estudantes de toda a América Latina, fizemos a abertura e depois a sala foi invadida por estudantes com lenços brancos no pescoço numa ação que, mais tarde viemos-a saber poderia ter gerado derramamento de sangue, se não tivéssemos conduzido com habilidade a situação. Eles entraram e se estabeleceu uma briga entre plateia e as pessoas que estavam invadindo, eram filhos de fazendeiros, outras pessoas da burguesia e estabeleceu uma briga e a certa altura eu propus que eles teriam direito de falar. (GALVÃO, 2004, p.27)

No dia 30 de março, estudantes tinham invadido e "empastelado" a cerimônia de abertura do $1^{\circ}$ Seminário Latino Americano de Reforma e Democratização do Ensino Superior, no auditório da antiga Faculdade de Odontologia do Pará - Localizada à época no Bairro da Batista Campos. Os invasores eram filhos de fazendeiros e policiais militares do Estado. Mickey Lobato entrou no salão interrompendo o discurso do representante da Nicarágua, gritando "vamos acabar com esta merda, bando de comunas, filhos da puta". Eles tinham lenços brancos no pescoço, para não serem confundidos com os "estudantes comunistas", deixando indicação para os PMs sobre o seu alvo.

O Diretório Acadêmico de Medicina da Universidade do Pará, em nota oficial publicada no jornal "Folha Vespertina” de 31de março de 1964, condena a invasão do II SLARDES, evento que estava sendo realizado em Belém e tinha como patrocinadores a UNE, UIE e UAP. O objetivo do Seminário era promover a discussão de proposições que contribuíssem com a proposta de Reforma Universitária em toda a América Latina, deixando clara também a intenção das lideranças estudantis quanto à defesa da reforma 
em anestesiar a luta do movimento estudantil pela reforma universitária e pela imprensa para impedir a ampliação do debate sobre a reforma universitária, que colocava em choque os limites de um sistema universitário que não conseguia atender toda a demanda existente e não tinha criado um projeto de Universidade que ampliasse a participação de estudantes no seu interior. O movimento estudantil colocava-se como articulador das reformas de base e da autêntica reforma universitária, bem como defensor da relação entre os povos da América Latina.

\section{NOTA OFICIAL}

A União dos Estudantes Paraense cumprindo decisão de seu congresso extraordinário ontem realizado. Considerando que se desenvolve no país um processo golpista contra o mandato do presidente da República e atendendo a orientação da União Nacional dos Estudantes.

\section{RESOLVE:}

1- Decretar greve geral dos universitários paraenses até que seja destruído todo esquema golpista que ameaça o Brasil;

2- Conclamar todos os oficiais, sargentos, trabalhadores, camponeses e o povo em geral para cerrarem fileiras em torno do presidente da República que encarna neste momento os sentimentos reformistas de libertação do povo brasileiro.

Belém, $1^{\circ}$ de Abril de $1964 .{ }^{20}$

Há tentativas de resistência ao golpe das forças armadas em 1964 em Belém. A União Acadêmica Paraense publica nota oficial no jornal "Folha Vespertina" em $1^{\circ}$ de abril, em que admite haver um processo de golpe contra o mandato do presidente; resolve decretar greve geral dos estudantes universitários paraenses e conclama a unidade política com outros segmentos da sociedade, notadamente soldados das forças armadas,

\footnotetext{
${ }_{19}$ Participaram deste evento estudantes de diversos países como Cuba, Guatemala, Porto Rico, Honduras, Argentina, Chile, Uruguai e Venezuela, além dos estudantes brasileiros como José Serra, Alberto Oliveira, Betinho, dentre outros.

${ }^{20}$ Nota Oficial. Folha Vespertina, 1 de abril de 1964.
} 

mudar o mundo, mas não somente isto os animava, o desejo de ver implantada no Brasil uma sociedade solidária, menos competitiva e acima de tudo nacionalista e voltada para o bem-estar da população mais pobre. A nota expressa também a noção de que os dirigentes da UAP viam-se na vanguarda da resistência ao golpe, colocando os estudantes como parte fundamental da aliança de forças capazes de dirigir o Brasil.

O “Jornal do Dia" veicula como o Governo Estadual, trabalhadores e estudantes esperavam o golpe. Em matéria do dia $1^{\circ}$ de abril de 1964 as primeiras figuras do governo faziam vigília quando começaram a circular em Belém as primeiras notícias de que a crise nacional se agravara. No gabinete do governador, encontravam-se vários secretários do governo, além do prefeito de Belém Isaac Soares. Newton Miranda, governador do Estado, acompanhou tudo pelo rádio e esteve o tempo todo com as forças armadas do Estado pensando em como manter a ordem e a segurança. Não houve questionamentos à quebra da normalidade democrática por parte das autoridades constituídas no Estado. Quem sai na defesa da democracia e da ordem são os estudantes, os trabalhadores vinculados a alguns sindicatos e lideranças estudantis, sindicais e partidárias. A Universidade silencia e vê-vários de seus discentes e docentes serem presos, torturados, constrangidos e submetidos a comissões de inquéritos.

O clima transcrito nos jornais era de tranquilidade e calma e o posicionamento do governo estadual era apenas de expectativa com relação à revolução. As lideranças sindicais no mesmo dia acataram a decisão da CGT de entrar em greve, tendo em vista a possibilidade de fechamento dos sindicatos e fizeram, também, a indicação de um representante para ir ao Rio de Janeiro saber das decisões tomadas mediante a situação que era de alerta aos trabalhadores. As lideranças estudantis de imediato convocaram uma greve, aceitando o decreto nacional lançado pela UNE em defesa das liberdades individuais.

A UAP se declara em vigília cívica, servindo de sede de informação para estudantes e populares. Por meio de um alto-falante que retransmitia a programação da "rede da 

só teve cumprimento em poucos estados. A inação era generalizada. Os estudantes eram as vozes mais barulhentas na denúncia do golpe militar, daí porque a invasão deveria funcionar como um cala-boca corretivo (ALVES apud GALVÃO, 2004, p.160).

Naquele momento, a UAP estava cheia de alunos. Todos evidentemente sabiam das movimentações. No dia $1^{\circ}$ de abril, por volta das 19 horas a UAP foi invadida por tropas do exército e tudo foi quebrado. Havia um teatro de arte popular, que foi destruído, o famoso TAP, uma versão Parauara do CPC da UNE (GALVÃO, 2004, p.16). Foram presos dois dirigentes do PCB no Pará, vestidos de cuecas e sapatos, Humberto Lopes e Jocelyn Brasil, sequestrados de suas casas. Na porta da UAP, as metralhadoras foram apontadas para a sede, com soldados deitados nas calçadas. Os estudantes fugiam pelos quintais enquanto a sede da UAP era destruída pelos soldados (GALVÃO, 2004, p.16).

Pedro Galvão, presidente da UAP, passou mais de 50 dias preso, indiciado em Inquérito Policial Militar. Os estudantes presos em 1964, quando falam de suas experiências, expressam o medo que vários setores da sociedade tinham do comunismo. Hoje a historiografia indica que o golpe de 64 foi um golpe preventivo, contra as reformas de base, medo da cubanização do Brasil e da implantação no pais de uma república sindicalista. Debate-se também que a democracia liberal, então implementada, não era em valor defendida pelos apoiadores de João Goulart e pelos golpistas. A democracia foi quebrada em sua defesa. Logo após o golpe o reitor Silveira Neto pede a renúncia da diretoria do DA de Filosofia, Ciências e Letras: Era diretor da Faculdade o Cônego Ápio Campos, que levou a proposta para as lideranças universitárias. Eles seriam transferidos para outros Estados caso aceitassem a renúncia. Sem a renúncia haveria a expulsão dos estudantes Roberto Cortez, Walter Pinheiro, Mariano Klautau, José Maria Platilha e Isidoro Alves. Apesar do pedido do reitor não houve a renúncia do DA de Filosofia,

\footnotetext{
${ }^{21}$ Professor aposentado da Universidade Federal do Amazonas. Estava na sede da UAP quando foi invadido pelo exército.
} 
Ciências e Letras, a não ser a do presidente. No mesmo momento, foi proposto pelo Coronel Alacid Nunes ${ }^{22}$ que houvesse eleições indiretas para os DAs, com triagem de nomes. O Dr. Silveira Neto foi informado por meio de um amigo do coronel Jarbas Passarinho ${ }^{23}$ que não era para expulsar estudantes, e assim os militantes terminaram seus cursos.

$\mathrm{Na}$ engenharia os soldados do exército fecharam o Diretório Acadêmico. Houve prisões na Filosofia, Ciências e Letras, que havia entrado em greve em 64, antes do golpe, conseguindo que os cursos da Faculdade voltassem a ter o bacharelado Direito, adquirido pelos ingressantes antes de 1962. No mesmo ano, após o golpe, há o fechamento do Diretório Acadêmico de Filosofia. Fica sob a responsabilidade do Major Alacid Nunes a presidência do IPM, que deveria apurar a existência de subversão entre os universitários.

Flávio Suplicy de Lacerda, Ministro de Educação e Cultura, em abril de 1964, institui as Comissões Especiais de Investigação Sumária (CEIS) em todas as Universidades brasileiras, pois de acordo com o artigo $7^{\circ}$ do Ato Institucional do dia 9 do mesmo mês e ano, em seu parágrafo $1^{\circ}$, determina a investigação sumária para a apuração da responsabilidade por atos contra a Segurança Nacional, o regime democrático e a probidade da administração pública. No Pará, a CEIS foi implantada pela portaria $n^{\circ}$ 239/64, baixada pelo reitor José da Silveira Neto. Foram nomeados para constituir esta comissão os professores Silvio Augusto de Bastos Meira (presidente), José Achiles Pires

${ }^{22}$ Alinhado aos objetivos do Regime Militar de 1964 foi alçado à condição de protagonista político quando o governador Aurélio do Carmo foi deposto e em seu lugar assumiu Jarbas Passarinho, que na condição de novo ocupante do Palácio dos Despachos, o nomeou prefeito de Belém em 1964,1 entretanto Alacid Nunes renunciou ao cargo a tempo de concorrer às eleições de 1965 quando foi eleito governador do Pará pela UDN e assim encerrou o predomínio do PSD na política estadual na última refrega antes do ciclo dos governadores biônicos.2 Tanto Jarbas Passarinho quanto Alacid Nunes ingressaram na ARENA após o bipartidarismo, sendo que o primeiro foi eleito senador em 1966, mas a convivência pacífica dos primeiros anos logo foi substituída por uma cisão interna que legou a cada um metade da máquina partidária e somente com a intervenção de Brasília os líderes recalcitrantes conseguiam dividir o mesmo espaço político.

${ }^{23}$ Em 15 de junho de 1964 foi empossado governador do Pará em lugar do deposto Aurélio do Carmo, cuja presença à frente do executivo foi dispensada pelo novo regime. Jarbas Passarinho filiou-se à ARENA e após deixar o governo1 foi eleito senador em 1966, mas em seguida foi nomeado ministro do Trabalho e Previdência Social no governo Costa e Silvaz sendo mantido no cargo pela Junta Militar de 1969 que assumiu o poder após o afastamento do presidente da República até que o presidente Emílio Garrastazu Médici o nomeou ministro da Educação.3 Em sua atuação como ministro de estado foi signatário do Ato Institucional Número Cinco em 13 de dezembro de 1968. 
dos Santos Lima e Agenor Porto Penna de Carvalho, assessorados pelo Major Antônio José do Carmo Ramos, indicado pelo Quartel General da Oitava Região Militar e Comando Militar da Amazônia (GODINHO, 1992, p.52). Para fazer cumprir o determinado no ato institucional, no dia 18 de maio de 1964, a CEIS da Universidade Federal do Pará inicia suas atividades expedindo circulares aos diretores de unidades, aos presidentes dos Diretórios Acadêmicos e a todo corpo docente da UFPA, solicitando remessa dos nomes de todos os suspeitos de práticas e atos delituosos, bem como a oportunidade de todos poderem apresentar denúncias. A Comissão pretendendo notificar a todos, também publica na imprensa um edital que concedia a qualquer interessado o direito de apresentar denúncia (GODINHO, 1992, p.52). Muitos estudantes foram levados para depor e

Foram presos: Pedro Galvão de Lima (direito), Francisco Costa (medicina), Almerinda Freire (serviço social), Raimundo Costa (direito), Ronaldo Barata (direito), Ubirajara Oliveira (engenharia), José Seráfico de Carvalho (direito), João de Jesus Paes Loureiro (direito), Heraldo Maués (filosofia), Walter Pinheiro (filosofia), Roberto Cortez (filosofia), Isidoro Alves (filosofia), Infante Henrique (medicina).

A Comissão tentou conhecer as correntes político-ideológicas dos estudantes, acreditando que no meio universitário havia três setores; os independentes, que seria a maioria; a ação popular em que relacionavam os nomes de Pedro Galvão, Inocêncio Coelho, Roberto Cortez, Antônio João Moreira Bastos e Pedro Lucena; e os comunistas Ronaldo Barata, Orlando Silva e Seráfico de Carvalho, correntes presentes na UAP. Todos os atos de investigação de inquéritos tiveram o apoio do reitor Silveira Neto ${ }^{24}$, pois no seu entendimento

A UAP era uma entidade particular, não era entidade universitária (...) porque naquele tempo os estudantes não tinham se unido e não havia Diretório Central. Além de considerar que a situação, nos anos sessenta, na universidade era um oásis, um mar de tranqüilidade. Não posso me queixar de nenhuma pressão militar (...) o General Jurandir Bezerra Mamedi era um homem inteligente, culto e uma pessoa muito educada. Tive com ele uma excelente relação de amizade e não sofri pressão nenhuma.

\footnotetext{
${ }^{24}$ Entrevista concedida por José da Silveira Neto. In: Documentário 30 anos UFPA. Belém: ADUFPA, 1987
} 
No mesmo ano do golpe, o diretor da Faculdade de Filosofia, Dr. Aloysio Chaves, recebe um expediente do "comando revolucionário" impedindo que Pedro Galvão seja o orador da turma. Foi a primeira vez que um orador de turma se via impedido de ler seu pronunciamento. O professor Edgar Contente não proferiu o seu discurso de paraninfo da mesma turma, em um belo gesto de solidariedade. ${ }^{25}$

Em 1967, a reitoria da UFPA apresenta ao Conselho Federal de Educação seu plano de reestruturação. O parecer da Comissão tirada para analisar esse plano no conselho Federal aponta vários problemas no plano proposto, dentre os quais destaca o não cumprimento das determinações legais previstas pela reforma universitária; o Conselho Universitário apresenta apenas as linhas gerais do plano. Quanto ao conteúdo do documento apresentado, verificaram-se os seguintes problemas: A Universidade e seus fins não se enquadram na filosofia reformista do Estado; quanto à estrutura, não se determina quais as unidades de ensino básico e de pesquisas deverão constituir a Universidade; não havia clareza quanto às funções dos departamentos; também não fica claro como se fará a integração entre ensino e pesquisa; qual a diferença entre Faculdades, Escolas e Institutos e ainda os Núcleos; na falta de consenso de alguns pontos, estes sempre são transferidos para o Estatuto; não havia discriminação de cursos e disciplinas; em geral, o plano básico se apresenta difícil e complicado. Deste modo, o parecer final é que o Plano Básico de Reestruturação da UFPA baixe em diligência e seja rediscutido na forma da Lei. $^{26}$

Havia um controle institucional na Universidade Federal implementado no ano de 1968, desde a implantação no Campus do Guamá na gestão de Silveira Neto pelo SNI (Serviço Nacional de Informação). Ocorreu uma constante vigilância dentro do campus, com professores presos, como o professor Heraldo Maués ${ }^{27}$, ameaçados, como o professor Júlio Ribeiro ${ }^{28}$, alunos que foram surpreendidos com denúncias ${ }^{29}$, as aulas

\footnotetext{
${ }^{25}$ GALVÃO, P. Vencido Vencedores. In: Galvão, Pedro. 1964 - Relatos Subversivos: Os estudantes e o golpe no Pará. Belém: Edição dos Autores, 2004, pp. 38.

${ }^{26}$ Parecer n ${ }^{\circ}$.379/67. Câmara de Ensino Superior - $2^{\circ}$ Grupo. Aprovado em 4 de outubro de 1967.

27 Professor perseguido pelo SNI, sendo impedido de contratação, mesmo tendo sido aprovado em 2 concursos em 1971, mas só foi contratado pela UFPA em 1972, no concurso de Antropologia.

${ }^{28}$ Professor do Curso de Química e na época era diretor do curso, ele era considerado um dos opositores do
} 
Estudos de Problemas Brasileiros, que eram ministradas por militares, e a retirada de temas do programa de vestibular e das disciplinas.

Em 4 de Janeiro de 1968, o diretor da Divisão de Segurança e Informações do MEC solicita algumas informações ao reitor Silveira Neto sobre a Universidade Federal do Pará, quanto ao corpo docente, ao corpo discente e a estrutura física da Universidade ${ }^{32}$. 0 reitor Silveira Neto em resposta ao documento envia aos diretores da Faculdade o pedido. O diretor da Escola de Serviço Social apresenta as informações dos professores lotados na referida escola, como suas ocupações atuais e anteriores, o local de trabalho, a sua religião, naturalidade, residência, nacionalidade, instrução, estado civil e filiação.

Em um comunicado confidencial $^{33}$ ao diretor da Escola de Serviço Social da Universidade Federal do Pará, o professor Eduardo Hermes, da Faculdade de Medicina, comunica que os alunos João Monteiro de Pina Neto e Evaldo Jesus de Miranda estão desligados da referida Faculdade por decisão do Conselho Administrativo diante da decisão da Comissão de Inquérito disciplinar, sendo ratificado pela portaria nº 375/1969, que proibia os alunos de matricular-se em outro estabelecimento de ensino pelo prazo de três, e foram enquadrados no decreto- lei $\mathrm{n}^{\circ} 477$.

Em 28 de fevereiro de 1968, depois de feitas as mudanças propostas pelo CFE no plano básico de reestruturação da Universidade e este ser aprovado, o reitor Silveira Neto

reitor Silveira Neto, que foi duramente perseguido, foi processado diante da intervenção que ocorreu na faculdade de Química.

${ }^{29} \mathrm{O}$ estudante Adelmo Lima Sales, foi um dos estudantes do curso de Medicina que o chefe da $\mathrm{ABE} / \mathrm{SNI}$ queria informações, de acordo com o Ofício $n^{\circ}$ 11/1974-A2. Outro documento referente ao discente Manoel Boaventura Monteira, matriculado no curso de Jornalismo que era estrangeiro natural de Cabo Verde, de acordo com o Ofício DERCA nº 1290/1980.

${ }^{30}$ Ofício Circular ao reitor da UFPA, Silveira Neto, $n^{\circ} 1 / 1968$.

${ }^{31}$ Em 05 de Abril de 1970, o coordenador do curso de Serviço Social recebe do coordenador do Centro Socioeconômico, o professor Clóvis Malcher, informações sobre o Diretório Acadêmico local e dos representantes discentes junto aos órgãos superiores da UFPA, em Ofício nº 236/1971.

32 Ofício Circular $n^{\circ} 1 / 1968$.

33 Ofício Confidencial $n^{\circ} 78 / 1970$. 

algumas modificações ${ }^{34}$. A aprovação do plano de reestruturação da Universidade Federal do Pará pelo Conselho Universitário passou a ser objeto de grande discussão no Conselho e entre os estudantes.

No dia 2 de julho de 1968, na sexta sessão do Conselho Universitário, o reitor José da Silveira deu conhecimento a todos que, a exemplo do ocorrido em outras Universidades, recebeu cópia do parecer do relator Newton Sucupira, do Conselho Federal de Educação, sobre o Plano de Reestruturação da Universidade Federal do Pará, que seria posteriormente apreciado pelo CFE.

Um dos pontos mais polêmicos e não aceito pelo parecerista foi à coexistência de duas unidades para a área de Química, uma no sistema de ensino e pesquisa básica (o Instituto de Química) e outra no sistema de unidades profissionais (a Escola de Química), destinada a ministrar o Curso de Química Industrial. A impugnação baseou-se no art. $4^{\circ}$ do Decreto Lei 252/67, que dispõe acerca de um sistema comum de ensino e pesquisa básicos, conferindo maior autonomia estrutural e funcional a estas áreas do saber. Dessa forma, fica claro para os conselheiros que deveria ser feito uma opção entre a Escola de Química e o Instituto de Química. O Conselho Federal de Educação, na Câmara de Ensino Superior, manifesta-se por meio do parecer $448 / 68$ de quatro de julho, aprovando o parecer de Newton Sucupira, ou seja, ratifica a impugnação feita a coexistência de duas unidades na área de Química, além de outras questões referentes a alguns setores da Universidade. Em vista desse fato, o Conselho propõe em seu parecer que o Instituto de Química ocupe-se também dos estudos ulteriores ao básico, inclusive o de Química Industrial, absorvendo a Escola de Química, ou esta concentraria todos os estudos de sua área, básicos ou profissionais.

O professor Júlio dos Santos Ribeiro, diretor da Escola de Química, em um ato considerado pelo reitor Silveira Neto como de insubordinação, viaja ao Rio de Janeiro

\footnotetext{
${ }^{34}$ A decisão é tomada após a participação em uma reunião de reitores no Conselho Federal de Educação e está registrada em ata da $2^{\mathrm{a}}$ sessão do Conselho Universitário realizada em 29 de fevereiro de 1968.
} 

Conselho Universitário, que havia decidido tender em favor do Instituto de Química. Denunciado pelo reitor Silveira Neto, na sétima sessão do Conselho Universitário, em 15 de julho, ressaltando que "de acordo com o estatuto ainda em vigor, essa matéria é da competência do reitor" que solicita ao Conselho que decida por uma punição ao diretor da Escola de Química. O Conselho acata o pedido e decide destituí-lo do cargo de diretor e aplicar-Ihe as penalidades mencionadas no art. 201, item I, do estatuto dos funcionários públicos. A portaria $n^{\circ} 580 / 68$ define que a direção da Escola de Química seria ocupada pelo Professor Arthur dos Santos Mello. Porém, na oitava sessão do Conselho Universitário de 29 de julho, José da Silveira declara que "no sábado, pela manhã, fui procurado pelo chefe do serviço de vigilância da Universidade, trazendo uma portaria de n 41/68, em que o Sr. diretor da Escola de Química, entregava a Escola aos Estudantes". 35

De acordo com a portaria $n^{\circ}$ 41/68, o diretor em exercício Júlio dos Santos Ribeiro, atendendo à solicitação do Diretório Acadêmico, autoriza este órgão estudantil a fazer uso das instalações da referida unidade durante o período noturno. A portaria continha ainda o seguinte adendo "o Conselho da Congregação da Escola de Química decidiu por unanimidade que os alunos permanecerão na escola 24 horas por dia, até solução final” 36 . Para obter maiores informações, o reitor convoca o diretor Arthur Mello, nomeado pela portaria 508/68, para que ele explicasse o que havia ocorrido. Em seu relato ao reitor, Arthur disse que "o Conselho da Congregação tinha-o destituído, reconhecendo apenas o direito ao diretor anterior". A questão, longe de ter uma solução definitiva, permanece como ponto de pauta em diversas sessões do Conselho. Os estudantes da Escola de Química ocupam de fato a Escola de Química 24 horas por dia, alastrando esse movimento por quase todas as Escolas, Institutos e Faculdades da Universidade Federal do Pará.

\footnotetext{
${ }^{35}$ Ata da $8^{\text {a }}$ Sessão do Conselho Universitário realizada em 29 de julho de 1968.

${ }^{36}$ Idem.
} 
No dia 2 de agosto de 1968, por ocasião da nona sessão do Conselho Universitário, o reitor Silveira Neto solicita a cada um dos conselheiros-diretores das unidades ocupadas por estudantes que informasse ao plenário a situação de suas unidades. O diretor da Faculdade de Direito, Lourenço do Valle Paiva, declara que "Os estudantes permanecem na faculdade, passaram lá o dia todo, estão realizando reuniões, não sei se vão deixar o prédio. (....) mas tudo me faz crer que eles não vão deixar o prédio, esta é a situação. 37 "O vice-diretor da Faculdade de Medicina, Gervásio de Britto Mello, declara que

Hoje, pela manhã, eu fui avisado que os alunos estavam pregando cartazes nas paredes da escola. Eu fui lá e eles declararam que quem arrancasse os cartazes seria castigado pela força bruta, então eu arranquei os cartazes e nenhum teve a coragem de me agredir (...) as duas e pouco recebo um telefonema de um amigo dizendo que eles iam ocupar a Faculdade às cinco horas em ponto (...) às cinco horas os funcionários desceram e foi uma comissão de alunos procurar o diretor para o ultimato, mas eu não estava lá para recebê-los. Creio mesmo que esta manifestação parte mesmo de uma minoria bastante pequena, mas um tanto exaltada, constituída pelos alunos das últimas séries (...). Alguns cartazes afixados na Faculdade dizem que é pacífica a ocupação, que não vão depredar absolutamente a Escola, é uma reação pacífica e alguns deles os mais exaltados tiveram a ideia de fazer uma marcha aqui contra a reitoria, é uma ideia que há entre os alunos. É mais ou menos o que se passou hoje na Faculdade de Medicina.

\section{O diretor da Escola de Serviço Social José Chaves Muller ${ }^{38}$ declara que}

Na minha escola, apesar de eu ter passado grande parte da tarde lá, não houve nada, nós encontramos apenas, ao voltarmos à tarde, a parede da frente toda escrita, com dizeres de que 'não devemos ficar isolados do movimento dos nossos companheiros'; 'abaixo Müller', etc. Ora, isso não tem importância, foi à única coisa que houve lá.

O diretor da Faculdade de Ciências Econômicas, Contábeis e Aturiais, Pedro José Martin de Mello, declara que "na Faculdade de Economia as aulas se desenvolvem normalmente, não temos conhecimento de maneira nenhuma, até o momento, de

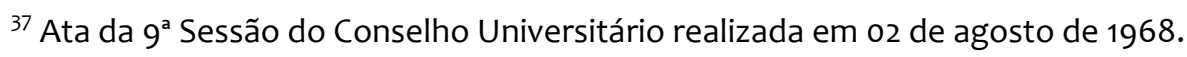

${ }^{38}$ Idem.
} 
qualquer anormalidade. 39 ". O vice-diretor da Faculdade de Filosofia Ciências e Letras, Orlando Sampaio Silva ${ }^{40}$, declara que

Durante o dia de hoje, as aulas funcionaram normalmente. Às 17:30, conforme estava previsto, teve início uma mesa-redonda que me foi solicitada por um grupo de estudantes do curso de Pedagogia. Eu vim da Faculdade neste momento, a mesa-redonda estava se realizando num ambiente pacífico, com a participação de vários professores (...) pedi à professora Anunciada Chaves, como membro mais antigo do Conselho Administrativo da Faculdade, que me representasse naquela mesaredonda (...) não existe na Faculdade nenhum cartaz, nenhuma faixa, nenhuma parede pintada e tive, há minutos atrás, uma entrevista com a aluna presidente do Diretório Acadêmico, que me repetiu a sua disposição de lutar até o fim contra qualquer medida de violência para a tomada da Faculdade, que ela acha que não deve haver.

O diretor da Faculdade de Odontologia, José Marcelino Cardoso Pingarilho, declara que "Apenas eu recebi agora à tarde um recado por alguns alunos de que amanhã, às 9 horas, uns alunos da Faculdade de Medicina irão tomar conta da nossa Faculdade, não sei se isto é verdade ou não. ${ }^{41}$ " O diretor da Escola de Engenharia, Omir Correia Alves ${ }^{42}$, declara que

Ontem, às 16 horas, foi realizada uma reunião do Diretório com um grupo de alunos, mais ou menos 150, o objetivo era o de debater a questão de certas deficiências em determinadas cadeiras, falta de material, professores que não estavam cumprindo o seu dever, etc. Após a reunião muitos foram embora, ficaram mais ou menos 50 alunos e um aluno, Boneff, pediu a palavra propondo a greve geral (...) então propôs que tomassem a escola. Então a minoria da escola que estava presente concordou. Após, o presidente do Diretório disse-me: 'Vim comunicar ao senhor que, em assembleia geral, resolvemos tomar conta da escola.

O vice-diretor da Faculdade de Farmácia Altino Chaves de Araújo declara que "não há nada de anormal, as aulas continuam normalmente". 43 O diretor do Instituto de Higiene e Medicina Preventiva, Abelardo dos Santos, declara que "o Instituto de Higiene

\footnotetext{
${ }^{39}$ Idem.

${ }^{40}$ Idem.

${ }^{41}$ Idem.

42 Idem

${ }^{43}$ Idem.
} 
está ocupado pelos alunos da Faculdade de Medicina". ${ }^{44}$ O diretor da Escola de Química, Júlio dos Santos Ribeiro ${ }^{45}$, declara que

$\mathrm{Na}$ Escola de Química, conforme comunicação dos alunos, eles informaram que deixariam de comparecer às aulas para promoverem conferências, etc., e isso ainda vem ocorrendo normalmente, até ontem tinha cartazes na frente da escola e que foram retirados. O resto está na normalidade, sem outros problemas.

O reitor Silveira Neto, insatisfeito com a declaração do diretor Júlio Ribeiro, solicitou-lhe que informasse se a Escola de Química estava ou não ocupada. Em reposta, Júlio Ribeiro disse que normalmente os alunos permaneciam lá. O reitor, ainda insatisfeito, ressalta que o normal é o aluno permanecer na unidade na hora de aula e que tal permanência após as seis horas da tarde lhe parece não ser normal e solicita novamente ao referido diretor, em nome da dignidade do Conselho, que informasse se os alunos ocuparam a escola. Respondendo a insistência do reitor à questão, Júlio Ribeiro se expressa da seguinte forma, “Bom, não existe propriamente uma ocupação, se é este o termo, a não ser que seja considerada assim a permanência constante dos mesmos na Escola". ${ }^{46}$ A professora Maria de Nazaré Sarges ${ }^{47}$ relatou que o clima era tenso, em 1968, na Universidade,

Houve uma tomada da Universidade, onde estava Celeste Medeiros, aí esses meninos de outras universidades, de outras faculdades iam para lá para fazer o cerão, e nós que eles consideravam os mais abestados íamos para rua fazer pedágio por que nós tínhamos que coletar dinheiro, pro café, pro cigarro, para quem ficava à noite, foi uma ocupação da Universidade, da Faculdade de Filosofia em 68. (.....) Os estudantes já estavam já querendo, enfrentar o governo devido às inúmeras perseguições que houve, com outros colegas universitários, que estavam sofrendo e também o nosso reitor também era meio linha dura, então se juntou todo mundo, no entanto, que o Aluísio não era lá do nosso prédio, e o Aluísio era da área de Agronomia e foi todo mundo para lá, e aliás, seu sempre digo que a Generalíssimo era o antro do subversivo, por que, tinha a faculdade de

\footnotetext{
${ }^{44}$ Idem.

45 Idem,

${ }^{46}$ Idem.

47 UNIVERSIDADE FEDERAL DO PARÁ. Reitoria. Universidade Multicampi - 25 anos de ensino superior regionalizado no Pará: entrevista Maria de Nazaré dos Santos Sarjes. Belém: UFPA, 2012. 1 vídeo (1h 08 min e 29 seg). Disponível em: <http://www.multimidia.ufpa.br/jspui/handle/321654/1066>. Acesso em: $07 / 08 / 2013$.
} 
Filosofia, tinha a faculdade de Medicina, que aquele povo todo assim, a irmã da Nilza, o Fiúza de Melo, todo aquele povo estava circulando por lá, o pessoal da Odontologia, era o corredor ali da oposição, vinha desde a Faculdade de Medicina até lá a Odontologia que era próxima a Brás de Aguiar, então houve essa ocupação, mas não levou uma semana essa ocupação. Logo depois desocuparam até porque não se tinha muita força para enfrentar, por que houve ameaça de expulsão da universidade, mas assim, nós que não podíamos ficar à noite, por que nós fazíamos o pedágio, era muito tenso porque, sempre estava a passar o carro de polícia, então quando a gente ouvia a sirene a gente corria e se escondia atrás das mangueiras, por que a gente tinha um pavor, até por que os nossos pais não sabiam que a gente estava metida nessa confusão.

No decorrer das discussões travadas no Conselho Universitário, salientou-se que este movimento já era previsto, pois até então tinha passado do Sul ao Nordeste e agora estava aqui na Amazônia, atingindo a juventude paraense, que, segundo Lourenço do Valle Paiva, até então era uma juventude calma e ordeira. Para o Conselheiro Silvio Augusto de Bastos Meira ${ }^{48}$ os acontecidos seriam por que

Os jovens, como nós já fomos, muitos são levados por alguns supostos líderes, agitadores profissionais que se infiltram nas escolas; outros existem sem opinião formada, alguns que querem apenas a perturbação da ordem, sem outro objetivo maior, de forma que também aí nós devemos separar o joio do trigo e levar o assunto com muito cuidado, a fim de evitar que as consequências sejam muito piores, porque ninguém se iluda, a juventude nunca foi derrotada: a história bem demonstra que a juventude nunca foi derrotada.

O professor Orlando Sampaio, indagado sobre a participação do reitor José da Silveira Neto no processo de ocupação da Universidade em 1968, diz que ele teve um comportamento estranho. Não tomou iniciativa de reagir contra o que estava acontecendo, preferia permanecer trancado em seu gabinete e "eu como diretor sabia que tudo o que acontecia era levado a ele por seus espiões". Afirma ainda que, em conversa com o reitor, comentou que a maioria dos estudantes da UFPA havia aderido ao movimento de ocupação. Segundo o professor Orlando Sampaio, o reitor Silveira Neto não tinha a mesma avaliação. Para ele, era apenas uma minoria que estava liderando esse movimento e a maioria estava silenciosa, omissa, ou seja, não estava participando, acreditando que essa maioria estava com ele, ao seu lado, por isso sua tranquilidade.

\footnotetext{
${ }^{48}$ Idem.
} 
Em 1968, o Diretório Acadêmico da Faculdade de Filosofia Ciências e Letras era extremamente atuante e, apesar da diversidade de ideologias políticas presente, os estudantes estavam unidos e pouquíssimas divergências eram perceptíveis entre eles. Com o Al-5, houve a confecção de uma lista de professores que seriam punidos nas universidades. Dentre os diversos professores que tinham seus nomes na referida lista, apenas Orlando Sampaio foi punido com a aposentadoria compulsória. Outro professor que teve sua aposentadoria compulsória foi Ruy Barata, cartorário, advogado, professor da UFPA, preso, destituído da função de cartorário, aposentado compulsoriamente da Universidade, e teve os direitos políticos suspensos ${ }^{49}$.

Na entrevista citada o professor Orlando Sampaio afirma que não sentia que havia a intenção de aposentá-lo em 1968. Esta intenção só teria aparecido após o surgimento do movimento pela eleição de um novo reitor, já que Silveira havia ultrapassado o tempo de seu mandato. Movimento liderado pelas quatro Faculdades (Filosofia Ciências e Letras, Serviço Social, Química Industrial e Economia) que tinham certa autonomia ante a reitoria.

Desde o início do mandato do professor Silveira Neto havia três grandes oposições a sua administração, o curso de Química, Farmácia e Serviço Social, referente ao Plano de Reestruturação da Universidade Federal do Pará e a Faculdade de Filosofia com relação à eleição para diretor e vice-diretor. A Faculdade de Filosofia, Ciências e Letras foi fundada como instituto em 1955, como uma instituição particular. Na FFCL havia grandes dificuldades de relacionamento com o reitor Silveira Neto, devido ao processo de eleição para eleger diretores e vice-diretores, pois, de acordo com o regimento o mandato de diretor, era de três anos e a cada três anos a congregação da Faculdade deveria convocar uma nova eleição, o que não ocorreu durante o período de 1962-1968, quando o professor Napoleão Figueiredo, ficou na direção da faculdade.

O professor Orlando Teixeira da Costa foi designado, pela congregação, para resolver o impasse que havia na Faculdade de Filosofia. O parecer do jurista Orlando Costa considerou o mandato de Napoleão Figueiredo como irregular (COSTA, 2007, p.59).

\footnotetext{
${ }^{49}$ De acordo com o Ofício Confidencial GR nº1/1979, que continha os processos 2252/64 e 4898/64, dos professores atingidos por Atos Institucionais.
} 
professores Benedito Nunes, Carlos Coimbra, Orlando Sampaio e a outra chapa com o professor Alfredo Boneff ${ }^{50}$.

O professor escolhido foi Benedito Nunes, que não assume por ter ido fazer um curso em Paris, e "eu fui escolhido vice-diretor e logo em seguida eleito por unanimidade, com apenas um voto em branco, o meu". Orlando Costa, que havia liderado o movimento de oposição à administração de Napoleão Figueiredo, foi o candidato que encabeçaria a lista tríplice endereçada ao reitor Silveira Neto. O professor Alfredo Boneff, candidato do reitor Silveira Neto, foi indicado para ser o diretor. O professor Orlando Sampaio foi escolhido para ser vice-diretor da Faculdade de Filosofia,

Quando o diretor da Faculdade, Alfredo Boneff, solicita licença e se afasta do cargo, Orlando Sampaio assume a Direção, e, segundo ele, este é o fato preponderante para a sua aposentadoria, pois a situação política da época não aceitava sua presença na Direção da Faculdade naquele momento. Orlando Sampaio ${ }^{51}$ acredita que incomodou a situação por sua postura política contrária ao governo, porque não aceita os militares no poder. Após ter declarado não ser contrário às forças armadas

Desde que as forças armadas estejam em seu estrito cumprimento constitucionais, no exercício de suas atribuições constitucionais, eu não tenho nada contra elas. Agora eu me oponho ao militarismo como um sistema político implantado em um país.

Orlando Sampaio apesar de ter sido eleito por unanimidade não fora nomeado diretor da Faculdade de Filosofia Ciências e Letras. Para o professor Orlando Sampaio ${ }^{52}$,

Os estudantes estavam afinados a um movimento internacional iniciado na França que lutava por uma universidade participativa, onde poderiam participar das decisões administrativas de seus colegiados, de opinarem

\footnotetext{
${ }^{50}$ Professor da Faculdade de Filosofia, sendo um dos aliados do reitor Silveira Neto.

${ }^{51}$ Idem

${ }^{52}$ Idem.
} 
na escolha de seus currículos, enfim, ter participação na escolha do caminho a ser trilhado em sua vida acadêmica.

As Faculdades foram ocupadas uma a uma, em 1968, e uma das últimas a ser ocupada foi a Faculdade de Filosofia Ciências e Letras devido à plena liberdade dada pelo diretor em exercício, Orlando Sampaio. Houve a imediata reação dos policiais, que permaneceram rondando as proximidades da Faculdade e, a pedido do diretor, os estudantes permaneceram no interior desta até a polícia se retirar do local. "Foi um momento difícil”, declara Orlando Sampaio. O posicionamento deliberado pelo Conselho Universitário, referente às ocupações, foi no sentido dos respectivos diretores das Escolas, Institutos e Faculdades promoverem o diálogo com os estudantes, com o objetivo de mostrá-los que a atitude desencadeada por eles era errada e que somente pelo diálogo é que poderiam chegar a algum lugar.

Os Estudantes da Escola de Química haviam iniciado o movimento por acreditar que o Plano de Reestruturação aprovado pelo Conselho Universitário iria extinguir o Curso de Química Industrial, o que, segundo o reitor José da Silveira, tratava-se apenas de uma falácia, pois o Plano de Reestruturação da Universidade Federal do Pará resolveu manter o curso em qualquer que fosse a solução ou a decisão do impasse.

Para o professor Roberto Santos ${ }^{53}$, o reitor José da Silveira Neto tornou-se arbitrário, culminando no prolongamento de seu mandato, fato denunciado na Faculdade de Filosofia Ciências e Letras, onde tomaram a iniciativa de formalizar a denúncia ao conselho universitário. Todo esse embate precipita o surgimento de um possível nome para substituir Silveira Neto, Aloísio Chaves seria o nome, considerado mais independente, teve seu nome incluído na lista. O professor Aloísio foi o escolhido, representando, segundo Roberto Santos, um novo período para a UFPA.

\section{O professor Roberto Cortez em seu relato ${ }^{54}$ a Universidade Federal do Pará} comenta sobre as restrições que ele e alguns professores tiveram durante o mandato do

\footnotetext{
53 Era professor da Faculdade de Ciências Sociais sendo um dos opositores de Silveira Neto.

${ }^{54}$ CORTEZ, Roberto. Quem estava na Kombi? In: Mello, Alex. (org.). UFPA 50 anos : relatos de uma trajetória. Editora Universitária da UFPA, Belém, 2007.
} 

se professor da UnB, o professor José Seráfico de Carvalho, tornou-se professor do Amazonas de Administração, o Pedro Galvão, atuante no movimento estudantil dos anos 60, que não conseguira torna-se publicitário, o professor Isidoro Alves que ano de 1971 foi aprovado em dois concursos na UFPA, nas disciplinas de Introdução à Sociologia e Técnicas e Metodologia de Pesquisa e não foi contratado, o professor Raimundo Heraldo Maués, que teve sua contratação indeferida, sendo admitido a UFPA somente em 1972, por intermédio do professor Napoleão Figueiredo, que solicitou a contratação para o reitor Aloísio Chaves. O professor João de Paes Loureiro, que teve sua contratação efetivada no curso de Comunicação somente em 1977, apesar de ter passado em vários concursos anteriormente.

Encontramos na documentação de 1973 na UFPA o comunicado do chefe do SNI em Brasília que "desaconselha o aproveitamento do professor Heraldo Maués na UFPA" 55 , bem como o ofício confidencial do chefe da AESI/UFPA informando que "a chefia da $\mathrm{ABI} / \mathrm{SNI}$ desaconselha o aproveitamento do professor João Jesus de Paes Loureiro na UFPA" 56 . Encontramos também documento do delegado geral do polícia federal solicitando o nome de professores, promotores de agitação e subversão no meio estudantil"57, assim como ofício do reitor Silveira Neto solicitando "informações das unidades sobre rumores de manifestações com caráter subversivo no $5^{\circ}$ aniversário da revolução de 31 de março de 1964" "58. Há documentos assinados pelo reitor Aracy Barreto encaminhando para o Secretário Executivo do Conselho de Reitores das Universidades Brasileiras com o nome de pessoas atingidas pelo atos institucionais, como os professores Epílogo de Gonçalves, Campos Henry Chrecralia Kayath, Camilo Silvio Montenegro Duarte, Orlando Sampaio Silva e Ruy Paranatinga Barata ${ }^{59}$, que confirma a

\footnotetext{
${ }^{55}$ Ofício $n^{\circ} 009 / 73$.

${ }^{56}$ Ofício Confidencial $n^{\circ}$ 018/73/AESI/UFPA.

57 Ofício ${ }^{\circ} 013 / 69$.

${ }^{58}$ Circular Confidencial GR n ${ }^{\circ} 3 / 69$.
} 
críticas ao regime ditatória implementado em 1964, com a ocupação das faculdades em várias universidades, inclusive na UFPA. No ano de 1968 a UFPA era administrada pelo reitor Silveira Neto, que planejou e organizou a instalação da Universidade Federal do Pará. A ASI foi pensada no contexto do pós 1968, com a instituição do Al-5. Podemos perceber que elas "serviam de canal para o exercício de pressão e controle sobre as reitorias, ações provenientes da cúpula do Estado e dos serviços de informação". (MOTTA, 2008, p.45).

Toda esta documentação faz parte do acervo, guardado no arquivo Central da UFPA, no fundo de correspondência dos reitores. A documentação trocada entre os reitores e os órgãos do SNI demonstra uma preocupação com a propaganda e as ações dos "subversivos" e comunistas nas IFES. Há uma obsessão em demonstrar a infiltração comunista

no entanto, muitas vezes as assessorias serviriam de canal para o exercício de pressão e controle sobre as reitorias, ações provenientes da cúpula do Estado e dos serviços de informação. Importava menos o assessoramento aos reitores e mais o fornecimento de informações para alimentar o sistema de segurança e repressão. (MOTTA, 2008, p.45)

O que podemos observar é que os anos sessenta demonstram que os governos militares tiveram um olhar, e várias ações para UFPA, que fez com que a universidade fosse efetivamente implementada. Podemos dizer que a UFPA foi criada pelas ações de homens como Silveira Neto, que colaboraram com os governos militares e que aproveitaram as políticas da ditadura civil-militar para modernizar a instituição.

A UFPA recebeu muitas verbas e atenção dos governos militares. Houve a modernização da universidade, em meio à repressão do movimento estudantil, a prisão e aposentadoria compulsória de professores. Fez-se a reforma universitária, que teve

\footnotetext{
59 Ofício Confidencial GR n ${ }^{\circ}$ 01/79.
} 
contestação na UFPA, com ocupação das faculdades em 1968. A reforma universitária só foi implantada na UFPA em 1971, apesar de seu debate ser de 1968.

Antes de 1968 a UFPA inaugurou seu campus no Guamá: com a benção do presidente Costa e Silva. Tivemos modernização, censura, triagem para contratação de professores, aposentadorias compulsórias, implantação da ASI, aplicação do 477 em meio a construção de prédios, laboratórios, Biblioteca Central, pavilhão de aulas, principalmente nas áreas tecnológicas. Este artigo é parte de uma pesquisa, ainda inicial, que pretende revelar memórias e histórias ainda escondidas da UFPA.

\section{Referências}

ARAÚJO, Maria Paula Nascimento. A Luta democrática contra o regime militar na década de 1970. In.: REIS, Daniel \& RIDENTI, Marcelo. \& MOTTA, Rodrigo.(Org.). O Golpe e a ditadura 40 anos depois (1964-2004). São Paulo: EDUSC, 2004.

BECKMANN, Clodoaldo. José da Silveira. Professor e gerente do ensino superior. In.: José da Silveira Neto. E o ensino superior do Pará. Belém: Conselho Estadual de Cultura, 2006.

BRASIL. Decreto-Lei $n^{\circ} 477$ de 26 de Fevereiro de 1969: Define infrações disciplinares praticadas por professores, alunos, funcionários ou empregados de estabelecimentos de ensino público ou particulares, e dá outras providências. Disponível em: <http://www.legisweb.com.br/legislacao/?id=62997. Acesso em: 06 Ago. 2013>.

CUNHA, Janaina. A Reforma Universitária de 1968 e o processo de reestruturação da UFRGS (1964-1972): uma análise da política educacional para o ensino superior durante a ditadura civil-militar brasileira. São Leopoldo, RS : Editora Universidade Vale dos Sinos. 2009.

FICO, Carlos. Além do golpe: a tomada do poder em 31 de março de 1964 e a ditadura militar. Rio de Janeiro: Record, 2004.

FONTES, Edilza. UFPA 50 anos: história e memória. editora universitária UFPA. Belém, 2007.

GALVÃO, Pedro. 1964. Relatos subversivos: os estudantes e o golpe no Pará. Belém: Edição dos Autores, 2004. 
GODINHO, Maria das Graças Monteiro. A luta dos estudantes paraenses pela democratização da Universidade: por que Reprimir? Universidade Federal do Pará, curso de Pedagogia, Belém: NAEA - Dissertação de Mestrado, 1992.

HALBWACHS, Maurice. A memória coletiva. São Paulo: Vértice, 1990.

LOUREIRO, João. O tempo que é do tempo que foi. In: Mello, Fiúza. UFPA 50 anos: relatos de uma trajetória. Belém: EDUFPA, 2007.

MARTINS FILHO, João Roberto. O movimento estudantil na conjuntura do golpe. In.: TOLEDO, Caio (Org.). 1964: Visões Críticas do golpe: democracia e reformas no populismo. Campinas: Editora da Unicamp, 1997.

MEIRA, Alcyr. Um indômito timoneiro. In.: SILVEIRA, José da. Professor e gerente do Ensino Superior. In.: José da Silveira Neto e o Ensino Superior do Pará. Belém: Conselho Estadual de Cultura, 2006.

MELLO, Alex Fiúza de. UFPA 50 anos: relatos de uma trajetória. Editora Universitária UFPA. Belém, 2007.

MOREIRA, Eidorfe. Para a história da Universidade Federal do Pará: panorama do primeiro decênio. Belém: UFPA, 1977.

MOTTA, Rodrigo Patto Sá. Incômoda memória: o arquivo das ASIS universitárias. Rio de Janeiro: Acervo, v.21, jul/dez, p.43-66, 2008.

POLLACK, Michael. Memória e identidade social. Revista Estudos Históricos, Rio de Janeiro, v.5, n.10, p.200-212, 1992.

REIS FILHO, Daniel Aarão. Ditadura militar: esquerdas e sociedade. Rio de Janeiro: Jorge Zahar, 2002.

REIS FILHO, Daniel Aarão; RIDENTI, Marcelo; MOTTA, Rodrigo Patto Sá. O golpe e a ditadura civil-militar: 40 anos depois (1964-2004). EDUSC, 2004.

SAVIANI, Demerval. Sociedade de classes e reformas Universitárias. Autores Associados. 2007 
Recebido em: 15/08/2013 Aprovado em: 04/11/2013

Universidade do Estado de Santa Catarina - UDESC Programa de Pós-Graduação em História - PPGH Revista Tempo e Argumento Volume 05 - Número 10 - Ano 2013 tempoeargumento@gmail.com 